\title{
PLVAP wt Allele
}

National Cancer Institute

\section{Source}

National Cancer Institute. PLVAP wt Allele. NCI Thesaurus. Code C103953.

Human PLVAP wild-type allele is located in the vicinity of 19p13.2 and is approximately 26

$\mathrm{kb}$ in length. This allele, which encodes plasmalemma vesicle-associated protein, may

play a role in the formation of caveolae. 